\title{
Original Paperbacks
}

\section{GOVERNMENT POLICIES AND ETHNIC RELATIONS IN ASIA AND THE PACIFIC}

\section{edited by Michael E. Brown and Sumit Ganguly}

This extraordinarily rich study challenges many widely aecepted premises. No single volume does as much to illuminate the role that deliberate policy choices play in the development of ethnic tensions in multiethnic states." - Sidney Jones, Executive Director, Human Rights Watch Asia CSIA Studies in International Security $-550 \mathrm{pp}$. $\$ 25$ paper

\section{PATHS TO PEACE}

\section{Is Democracy the Answer?} edited by Miriam Fendius Elman

Scholars have long noted the apparent absence of wars between democracies. This book attempts to answer the question of whether a world of democracy would be a world without war. CSIA Studies in International Security 4450 pp. \$22.50 paper

\section{AMERICA'S STRATEGIC CHOICES}

edited by Michael E. Brown, Owen R. Coté, Jr., Sean M. Lynn-Jones, and Steven E. Miller

This reader describes the range of options for overall U.S. political and military strategy in the present environment, providing a provocative and thoughtful comparison of alternative strategies for American foreign policy, including the pursuit of primacy, coopera tive security, selective engagement, and retrenchment.

IS Reader $\bullet 360$ pp. \$18 paper

\section{ALLIES DIVIDED}

The Greater Middle East and Transatlantic

Policies for the Greater Middle East edited by Robert D. Blackwill and Michael Stürmer

This book looks at how Europe and the United States might agree upon and effectively coordinate their policies toward the Greater Middle East.

CSIA Studies in Intemational Security -350 pp. $\$ 20$ paper 


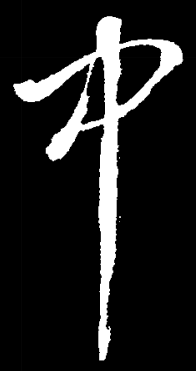

THE
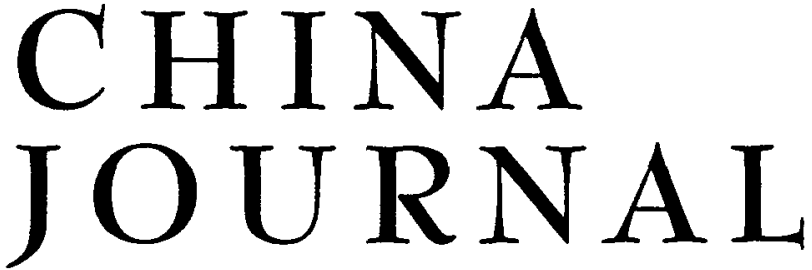

Currently the most interesting journal in the field.

Andrew Walder, Stanford University

The liveliest periodical in the field of contemporary Chinese studies. Feisty, enterprising, informed, and current.

Andrew ). Nathan, Columbia University

The single best scholarly journal on contemporary China. If one has to limit oneself to one journat on China it should be The China lournal.

Edward Friedman, University of Wisconsin

Has recently become the hottest, most-cited journal on contemporary Chinese affairs. Wide-ranging and timely. Thomas Gold, Berkeley

Fast becoming the leading journal of contemporary Chinese studies.

James L. Wotson, Harvard University

Now clearly the best journal in the field. Consistently insightful. Frederick Teiwes, University of Sydney

Subscription Rates (two 230-page issues per year - plus a free issue for new subscribers): Within Austraiia: $\$ 25$ per year, students $\mathbf{2 0}$, institutions $\$ \mathbf{1 0}$. Outside Australia: US\$2S per year, students US\$20, institutions US\$40; or the equivalent in other currencies. New 3-year subscriptions: $\$ 60 / U \$ \$ 60$, institutions $\$ 100$ - plus 2 complimentary issues.

I would like a: $\square$ 1-year $\square$ 3-year subscription

$\square$ Enclosed is my check (payable to The China Joumal)

$\square$ Please charge to my $\square$ Bankcard $\square$ Mastercard $\square$ Visa

Card No. Exp. Date

Name Signature

Address

Payments to: Contemporary China Centre, RSPAS, The Australian National University, Canberre, ACT 0200. 


\section{Bureaucracy and Race}

Native Administration in South Africa

\section{Ivan Evans}

"Most writing on South

Africa-scholarly and otherwise- has concentrated on showing what it meant for Africans to be caught in the web; Evans writes about what it meant to spin it."

-Frederick Cooper, author of Decolonizotion $\$ 55.00$ cloth and African Society

\section{The Challenge of Fundamentalism}

Political Islam and the New World Disorder

\section{Bassam Tibi}

Tibi offers an important and disquieting analysis of the particular synthesis of religion and politics known as Islamic fundamentalism. Comparative Studies in Religion and Society, $\$ 29.95$ cloth
Iconography of Power

Soviet Political Posters under Lenin and Stalin Victoria E. Bonnell

"A worthy contribution both to the study of Russia's visual arts in the Soviet era and to sociology and political thought in the Soviet Union down to the 1950s."

-S. Frederick Starr, author of Red and Hot Studies on the History of Society and Culture, A Centennial Book, $\$ 48.00$ cloth, illustrated

Neither Gods Nor Emperors

Students and the Struggle for Democracy in China Craig Calhoun "[Calhoun's] analysis of the whos and the whys of the Tiananmen protest is excellent." - Times Literary Supplement Winner, Best Recent Book in Political Sociology, ASA, $\$ 15.95$ paper

\section{The $S_{\text {now }}$ Lion and the Dragon}

China, Tibet, and the Dalai Lama Melvyn C. Goldstein

"A marvelously informative and realistic look at both how China and Tibet reached their present impasse and how their differences might yet be peacefully resolved."

-Orville Schell, author of Mandate of Heaven $\$ 19.95$ cloth, illustrated

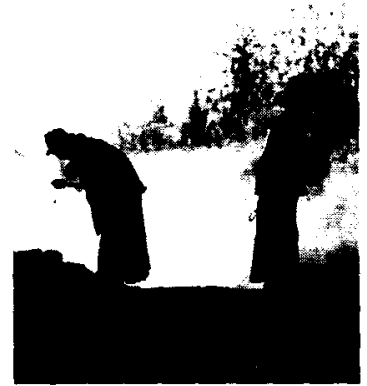

Local Power in the Japanese State Muramatsu Michio Translated by Betsey Scheiner and James White "Muramatsu's scholarship on the subject is the best available anywhere, and his boldly revisionist arguments are both provocative and persuasive."

- Haruhiro Fukui, author of Party in Power $\$ 45.00$ cloth, $\$ 16.95$ paper

The Paradox of Plenty

Oil Booms and Petro-States Terry Lynn Karl

Karl explains why, in the midst of two massive oil booms in the 1970s, oilexporting governments as different as Venezuela, Iran, Nigeria, Algeria, and Indonesia chose common development paths and suffered similarly disappointing outcomes. Studies in International Political Economy. $\$ 55.00$ cloth, $\$ 22.00$ paper

www.ucpress.edu At bookstores or order 1-800-822-6657.

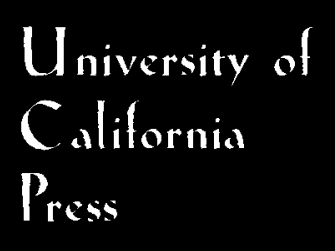




\section{A Russian Journal of World Politics, Diplomacy and International Relations}

\section{The only English-language foreign policy journal from Russia}

Known for its close ties with the Russian Foreign Ministry, International Affairs offers unique insight and analysis of the major foreign policy and security problems facing Russia and the other countries of the former Soviet Union, and presents a variety of inter-

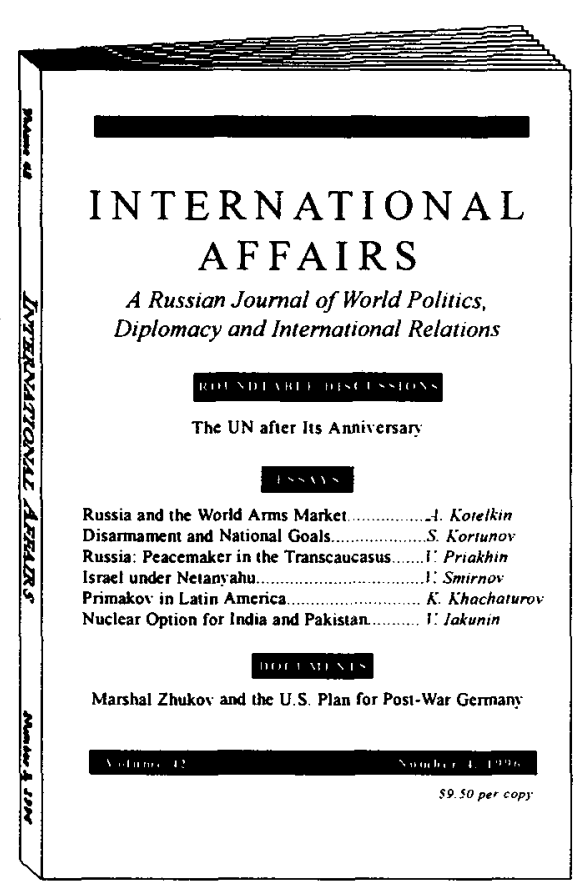

Send your orders 10

East View Publications, Inc.

3020 Harbor Lane North

Minneapolis, MN 55447, USA

tel: (612)550-0961 fax: (612)559-2931

email: eastview@eastview.com http://www.eastview.com pretations of world and domestic events by leading Russian policy makers and commentators. Indispensable research tool for scholars, analysts, executives and students of Russia and $\mathrm{CIS}$.

\section{EDITED bY BORIS PIADYSHEV BIMONTHLY, ISSN 0130-9641}

\section{SUBSCRIPTIONS}

Individuals: US \$39; Elsewhere \$69. Institutions: US \$129; Elsewhere \$139.

"ᄆ Please start my one-year subscription

Enclosed is my check or money order

D Charge to my Visa, Mastercard or AmEx Acct. No.

IExp. Date

1

Send to

Name

Company

Address

Address

ICity/State/Zip

ICountry IPhone 


\section{"An excellent survey of U.S. foreign policy."-Library Joumal}

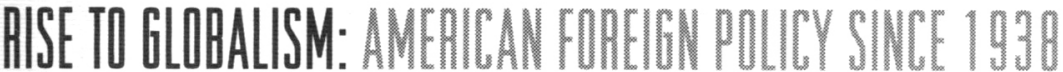
STEPHEN E. AMBROSE \& DOUGLAS G. BRINKLEY

ncorporating the most recent scholarship, this eighth revised edition of Rise to Globalism offers a concise and informative overview of the evolution of American foreign policy from 1938 to the end of the first Clinton administration, focusing on such pivotal events as World War II, the Cuban missile crisis, Vietnam, and the SALT MM treaties. Ambrose and New 4 Brinkley closely exam8 th 2 ine such recent topics as the Iran-Contra scandal, free elections in Nicaragua, the rise of international terrorism, the fall of Communism, the Gulf War, the crisis in Bosnia, and President Clinton's international trade policy.

"One of the most lively and provocative interpretive studies of the major events in recent American diplomatic history."-American Historical Review.

Penguin 0-14-026831-6 428 pp. 14.95

$$
\text { PENGUIN PUTNAM INC. }
$$

\section{academic MaAketing depaAtMent - 375 HUDSON St. · NY. NY 10014} http://www.penguin.com 


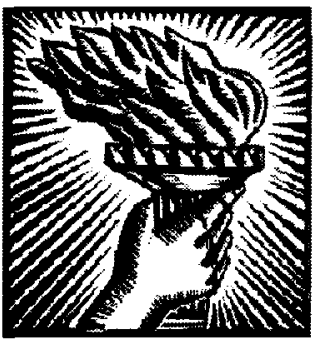

CONSOLIDATING THE THIRD WAVE DEMOCRACIES

edited by

Larry Diamond, Marc F. Plattner, Yun-han Chu, and Hung-mao Tien

\section{Complete Edition}

$\$ 45.00$ hardcover

Themes and Perspectives

$\$ 14.95$ paperback

Regional Challenges

\$14.95 paperback

\section{A Journal of Democracy Book}

The global trend that Samuel P. Huntington has dubbed the "third wave" of democratization has seen more than 60 countries experience democratic transitions since 1974. While these countries have succeeded in bringing down authoritarian regimes and replacing them with freely elected governments, few of them can as yet be considered stable democracies. Most remain engaged in the struggle to consolidate their new and fragile democratic institutions. Consolidating the Third Wave Democracies provides an in-depth analysis of the challenges that they face.

In addition to the complete hardcover edition, Consolidating the Third Wave Democracies is available in two paperback volumes, each introduced by the editors.

The first paperback volume, Themes and Perspectives, addresses issues of institutional design, civil-military relations, civil society, and economic development. It brings together some of the world's foremost scholars of democratization, including Robert $\mathrm{A}$. Dahl, Samuel P. Huntington, Juan J. Linz, Guillermo O'Donnell, Adam Przeworski, Philippe C. Schmitter, and Alfred Stepan. The second paperback volume, Regional Challenges, focuses on developments in Southern Europe, Latin America, Russia, and East Asia, particularly Taiwan and China. It contains essays by leading regional experts, including Yun-han Chu, P. Nikiforos Diamandouros, Thomas B. Gold, Michael McFaul, Andrew J. Nathan, and Hung-mao Tien.

\section{THE JOHNS HOPKINS UNIVERSITY PRESS}

Hampden Station, Baltimore, MD 21211

1-800-537-5487 • http://jhupress.jhu.edu/home.html 


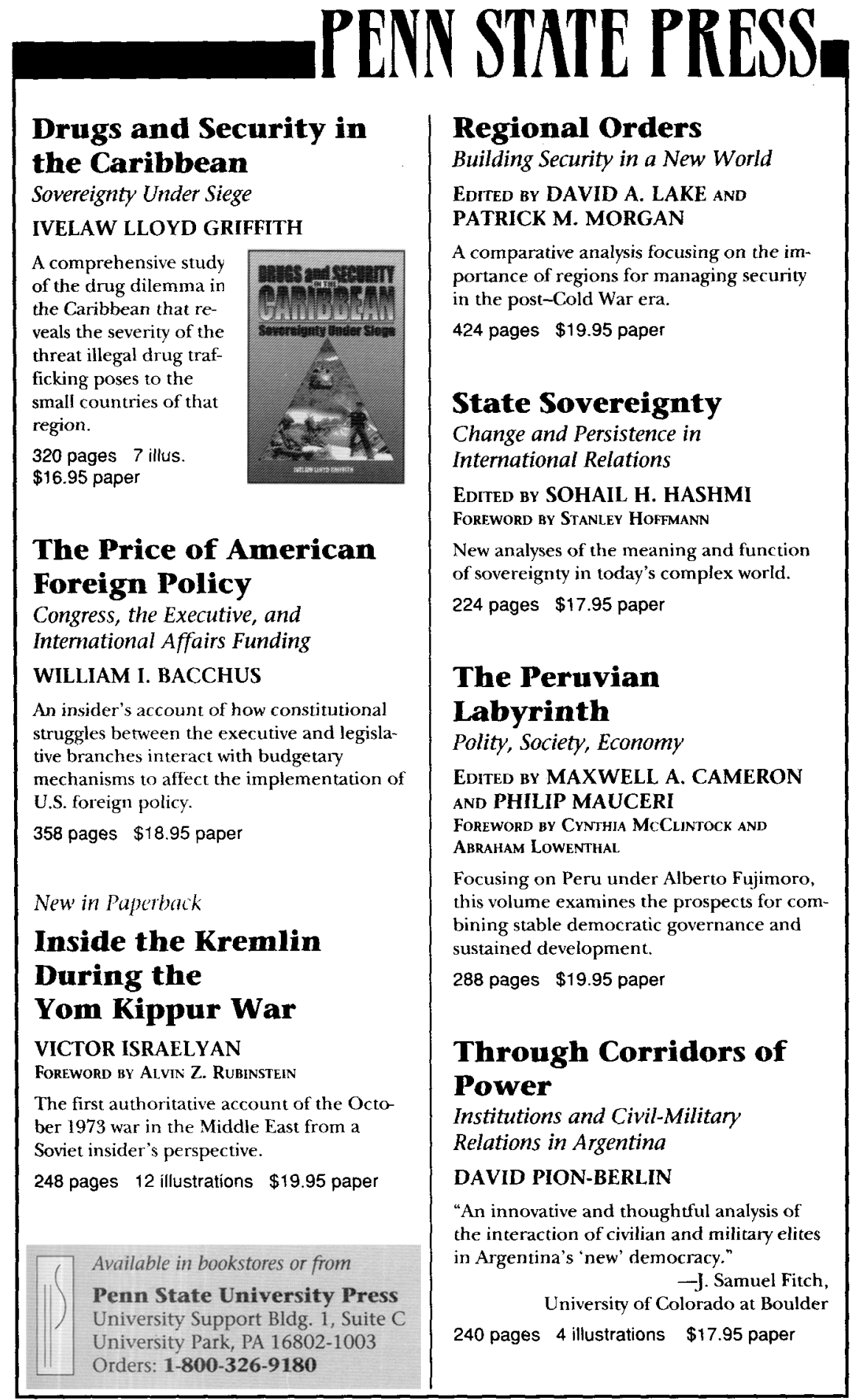




\section{THE BEST II POLITICS}

Keeping the Peace

Multidimensional UN Operations

in Cambodia and El Salvador

Michael W. Doyle, Ian Johnstone, and Robert C. Orr, Editors

This book explores the new multidimensional role that the United Nations has played in peacemaking, peacekeeping and peacebuilding over the past few years.

Contributors: Michael W. Doyle, Ian Johnstone, Robert C. Orr, David Chandler, Jin Song, Nishkala Suntharalingam, Cheryl $M$. Lee Kim, Mark Metrikas, Brian Williams, Elisabeth Uphoff Kato, Edelberto Torres-Rivas, Mark Levine, Timothy A. Wilkins, David H. McCormick, Granciana del Castillo

58185-0 Hardback \$64.95

58837-5 Paperback \$24.95

\section{The Polltics of}

\section{Open Economies}

Indonesia, Malaysia, the Philippines and Thailand

\section{Alasdair Bowie and Danny Unger}

This book asks why some countries have responded to the external constraints and opportunities posed by their global and regional economic context by opening up their economies. It examines the role domestic political and economic factors play in shaping the decision to become more open, or more inward-looking.

Cambridge Asia-Pacific Studies 4

58343-8 Hardback $\$ 59.95$

58683-6 Paperback \$18.95

\section{Passages to Power}

Legislative Recruitment

in Advanced Democracies

Pippa Norris, Editor

This comparative account of legislative recruitment applies a common analytical framework and new survey data to nineteen advanced democracies.

Contributors: Pippa Norris, Ian McAllister, Lynda Erickson, Voitto Helander, Bernhard Wessels, Haruhiro Fukui, Monique Leijenaar, Kees Niemoller, Helena Catt, Joni Lovenduski, Paul S. Herrnson

59099-X Hardback

59908-3

Paperback

about $\$ 59.95$

about $\$ 18.95$
Along the Domestic-Foreign Frontier

Exploring Governance in a Turbutent World James N. Rosenau

Rosenau explores the enormous changes that are currently transforming world affairs. He argues that the dynamics of economic globalization, new technologies, and evolving global norms are clashing with equally powerful localizing dynamics. The resulting encounters between diverse interests and actors are rendering domestic and foreign affairs ever more porous and creating a political space, designated as the "Frontier," wherein the quest for control in world politics is joined.

Cambridge Studies in International Relations 53

58283-0 Hardback \$59.95

58764-6 Paperback $\$ 22.95$

Innovation and

Transformation in

International Studies

Stephen Gill and

James H. Mittelman, Editors

This collection of original essays explores the relationship between theoretical innovation in international studies and historical transformations. Leading scholars reflect on the flux, uncertainty and transformation of world orders, and sketch the contours of the emerging world order.

Contributors: Stephen Gill, Enrico Augelli, Craig Murphy, Richard Falk, Mustapha Pasha, Mitchell Bernard, Eric Helleiner, Jeffrey Harrod, Kees van der Pijl, Mark Rupert, Fantu Cheru, Randolph Persaud, V. Spike Peterson, Yoshikazu Sakamoto, James Rosenau, Susan Strange, James Mittelman

59105-8 Hardback \$59.95

59903-2 Paperback \$22.95

Available in bookstores or from

\section{CAMBRIDGE UNIVERSITY PRESS}

40 West 20th Street, N.Y., NY 10011-4211

Call toll-free 800-872-7423

MasterCard/VISA accepted. Prices subject to change. Web site: http:/hnww.cup.org 


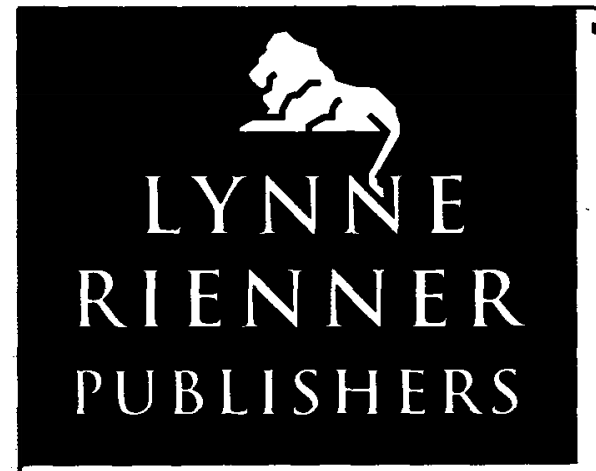

\section{FORTHCOMING! Anarchy and Order} The Interplay of Politics and Law in International Relations

James C. Hsiung he $\$ 55$

\section{Globalization}

\section{Critical Reflections}

edited by

James H. Mittelman

"One of the best books we currently have on [the subject]. Thought-provoking and recommended."

-Roger Tooze

hc $\$ 49.95$ • pb $\$ 19.95$

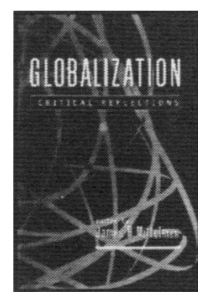

\section{The Anthropology of Anger}

Civil Society and Democracy in Africa Célestin Monga

"Excellent.... this book should be required reading for Africanists."

-M.E. Doro, Cboice he $\$ 47$

\section{The International Politics of the New Asia Pacific \\ Derek McDougall hc $\$ 55 \bullet$ pb $\$ 19.95$}

\section{The Arms Dynamic in World Politics}

Barry Buzan and Eric Herring

"This is a winner - a signal contribution to the fields of security/strategic studies and peace studies... raises all the essential issues and cuts through hundreds of books and articles to get at the center of matters relating to arms in international relations."

-Kal Holsti he $\$ 59.95 \bullet$ pb $\$ 22.50$

\section{Global Europe The European Union in World Affairs Christopher Piening}

"[This] is the best current overview of the subject. Uniquely informative, accessible, and comprehensive, it is a most welcome contribution from a world-wise insider." - Gary Marks

hc $\$ 49.95 \bullet \mathrm{pb} \$ 19.95$

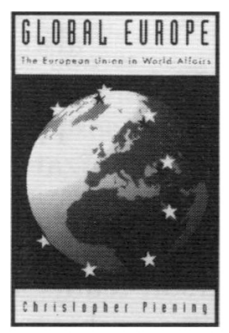

\section{FORTHCOMING! \\ Warlord Politics and African States} William Reno hc $\$ 49.95$

\section{Political Islam Revolution, Radicalism, or Reform? \\ edited by John L. Esposito}

"A first-class team of scholars provides recent information on Muslim politics across the world and highlights key themes that condition those politics... Lucidly written and cogent in analysis." - James Piscatori

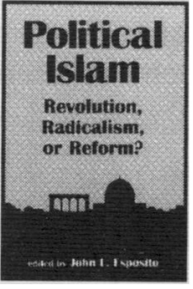
he $\$ 55 \bullet \mathrm{pb} \$ 19.95$ 


\section{MacArthur Foundation}

The Program on Global Security and Sustainability of the John D. and Catherine T. MacArthur Foundation announces an annual competition for grants for Research and Writing. Grants are available for the following purposes: to support innovation and excellence in the analysis of the causes, nature, and

Research consequences of international conflict and cooperation, and in the development of improved understandings of human security; and to broaden and strengthen the community of writers and

\section{and Writing peace, security and sustainability. scholars engaged in work on global} The Program seeks to support research and writing projects, in any academic discipline or profession, that promise to illuminate the dynamics of international security or multilateral cooperation. It also fosters creative work conducted outside

Grants of traditional disciplinary and professional approaches. Grants may be used in university and organizational settings or may support independent researchers working outside of institutional contexts. Projects to be carried out by individuals and by twoperson teams are eligible for support. Projects related to research or writing of the doctoral dissertation are not eligible for awards. Also ineligible for consideration are proposals to hold workshops or conferences; to produce textbooks, manuals, films, works of photojournalism or works of fiction; to edit volumes; or to develop circular materials. Applicants may request up to $\$ 75,000$ for individual projects, or $\$ 100,000$ for two-person collaborations. In 1998, Research and Writing will be an annual competition. Applications must be received by February 2, I 998 to be considered, and grant awards will be announced in September. Projects may be scheduled to begin as early as October 1, 1998. For further information about grants for Research and Writing and a brochure describing how to apply, please contact the Program on Global Security and Sustainability at:

The John D. and Catherine T.

MacArthur Foundation 140 South Dearborn Street Chicago, IL 60603 USA (312) 726-8000 e-mail: 4answers@macfdn.org Internet: www.macfdn.org

Program on Global

Security and Sustainability

An open

competition for research and writing projects related to

global

security and peace. 


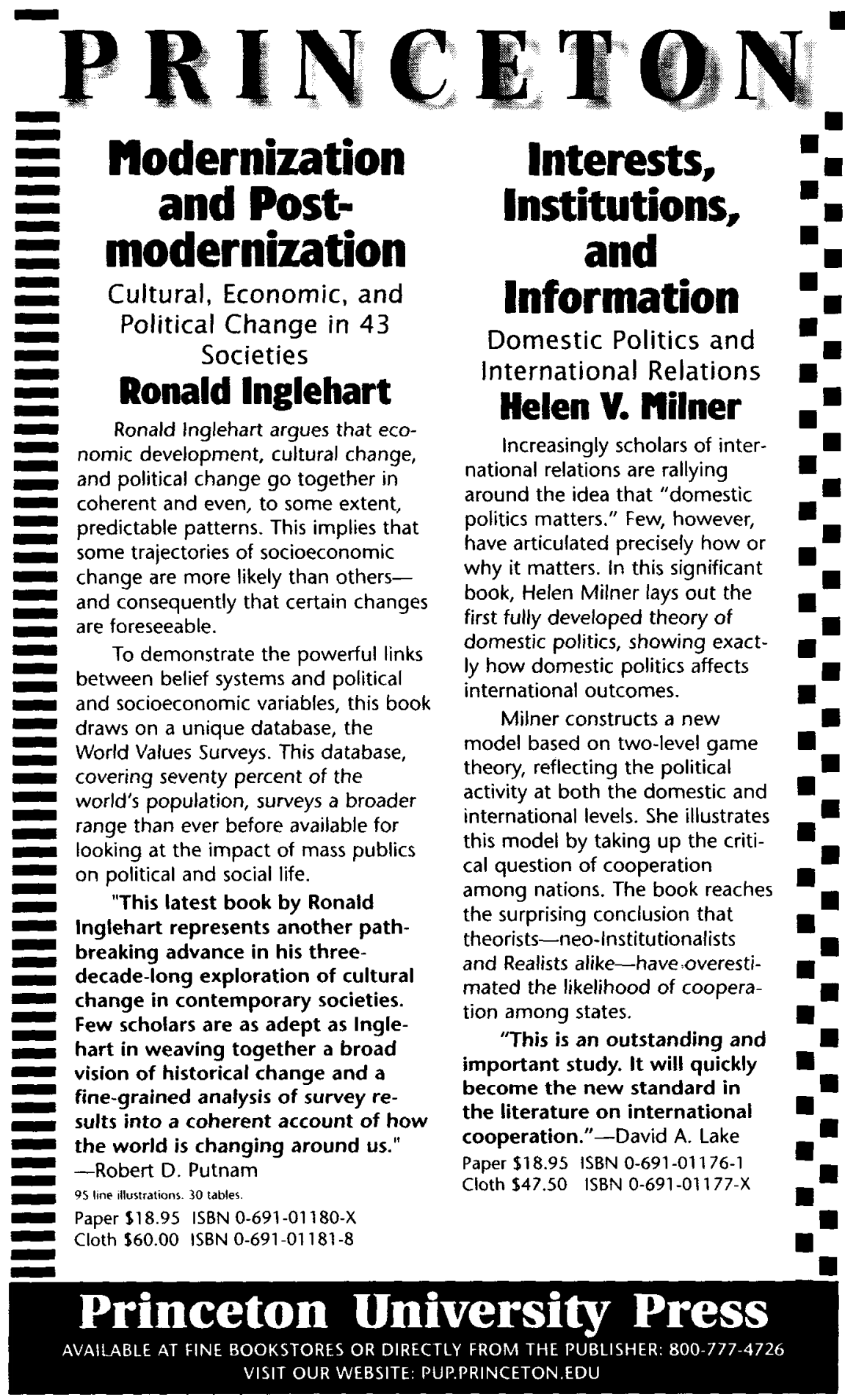




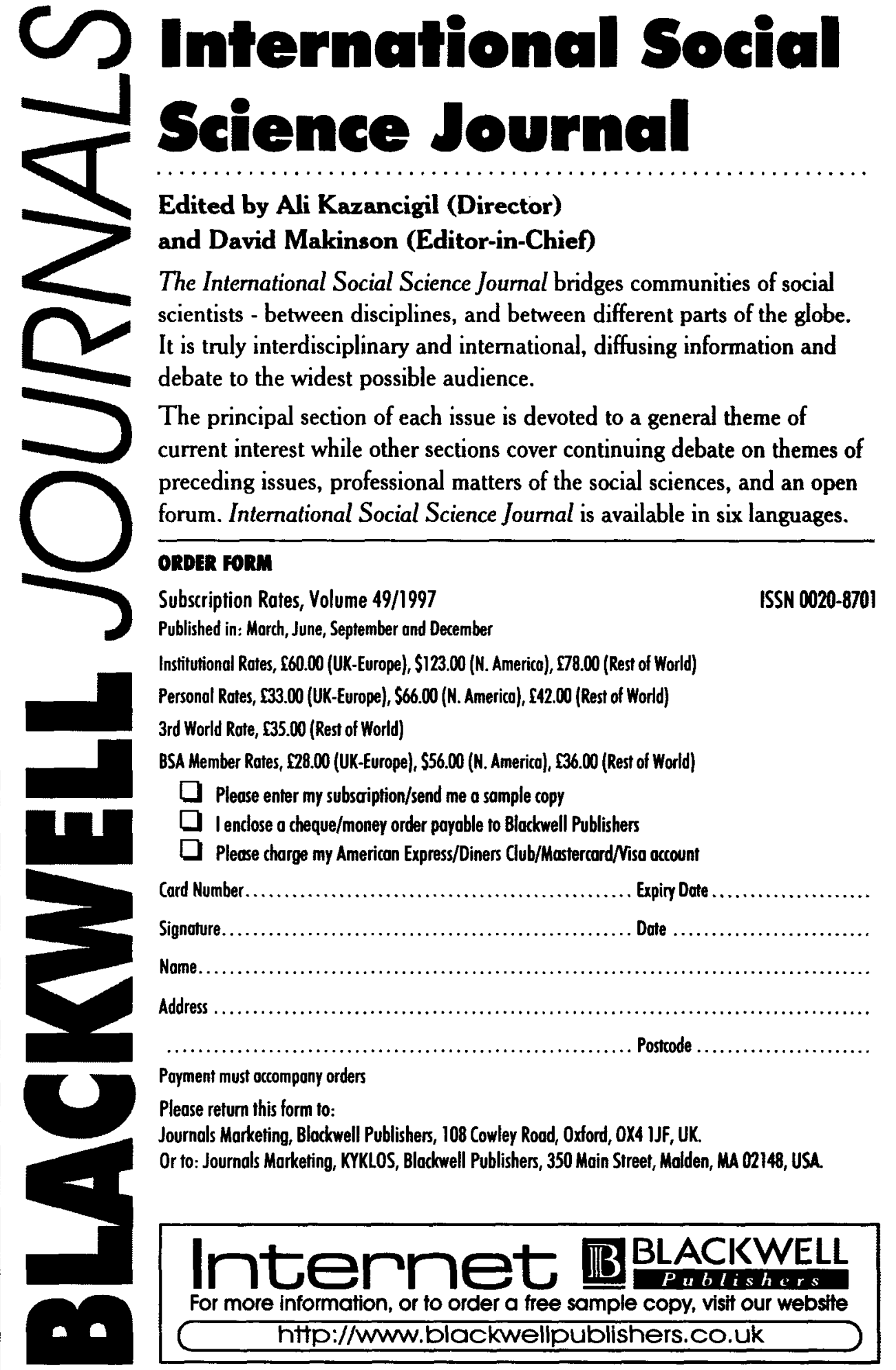

